\title{
Emancipating Minds and Practicing Freedom: A Call to Action
}

\author{
Lorlene Hoyt
}

\begin{abstract}
The generative utility and relative permanence of higher education institutions suggests they may have a vital role in contributing to our collective survival, if they are able to evolve quickly and purposefully. This essay is a reflection on my own experience of the academy and the ways in which the Ernest A. Lynton Award for the Scholarship of Engagement opened my mind and emboldened me to work hand-in-hand with communities nearby and around the world. In doing so, it makes the case for the practice of "reciprocal knowledge" to enhance human dignity and wellbeing and improve social harmony and stability. It is also a call to action, inviting people inside and outside the academy to contribute to the growing global university civic engagement movement.
\end{abstract}

Keywords: scholarly engagement; university civic engagement; reciprocal knowledge; human dignity

\section{Emancipation of Self}

Universities must be places where minds are emancipated and citizens enabled to live fully conscious lives in which suggested inevitabilities are constantly questioned.

_President Michael D. Higgins of Ireland, Address to EUA Conference, 2016

The university, for tenure-track professors and others, can become an intellectual prison, an environment where you learn to follow the long-established rules in order to survive. This essay is a call to action, aiming to reach and mobilize learners in the academy who might feel alone and trapped in an institution that primarily rewards conformity. As I recount my own experience of the academy, I reflect on the ways in which the Ernest A. Lynton Award for the Scholarship of Engagement opened my mind and set me free.

As I write, I represent both a "midpoint" and a "turning point" in the 23 -year history of the Ernest A. Lynton Award for the Scholarship of Engagement. As the midpoint, eleven engaged scholars received the Lynton Award (1996-2006) before I received the award in 2007 and there have been eleven award recipients since (2008-2018). More importantly, 2007 was a turning point for the award: I was the first person to receive the award who was not tenured. As an assistant professor on the tenure-track when I received the award, the public recognition of my engaged scholarship and the invitation to join a renowned cadre of scholars buoyed my otherwise floundering confidence. The award was also significant to me because it helped me understand and articulate my collaborative approach to research, teaching, and service.

The day I presented my engaged scholarship and accepted the award was at once the best and worst moment of my academic career. At the time, I was suffering from a migraine headache that was in its second week. The stresses of striving to meet the demands of tenure were mounting 
and I was under the care of two cardiologists. However, my conversation with Carla Lynton (Ernest's wife) at the Coalition of Urban and Metropolitan Universities Annual Conference in Baltimore was the catalyst for my scholarly awakening.

For several years as an assistant professor of urban planning at the Massachusetts Institute of Technology (M.I.T.), I had co-led a campus-city partnership known as MIT@Lawrence. (The City of Lawrence, Massachusetts, is a vibrant majority Latino city located about 30 miles north of M.I.T. It is the last textile city built by the Essex Company, one of the country's first corporations.) What began as a seven-week course aimed at teaching students of urban planning how to analyze data from the U.S. Census Bureau using a geographic information system evolved over time into a long-term collaboration in community development.

Prior to meeting Carla Lynton and receiving the award, I had strategically prioritized my time and efforts to align with the categories by which my colleagues would evaluate my scholarly productivity and impact: research, teaching and service. The news of achieving the Lynton Award prompted me to rethink, reframe, and rewrite the narrative statement that I had been preparing for my scholarly dossier for promotion to associate professor without tenure (the rank preceding tenure at M.I.T.). The award taught me to see the ways in which my research, teaching, and service were overlapping and mutually reinforcing, and it exposed me to the idea of the scholarship of engagement (Lynton, 1994).

Instead of examining the people of Lawrence as subjects of research (an approach that I had conformed to as a doctoral student), the award emboldened me to expand my engagement with community leaders in Lawrence and M.I.T. faculty and students in ways that cut across the traditional domains of research, teaching and service. Together, we blended the theory and practice of urban planning, studying and enacting solutions to problems of vandalism, flooding and foreclosure. We secured funding from the U.S. Department of Housing and Urban Development and deployed participatory methods of data collection and analysis to discover new development opportunities; we combined traditional spatial data with unconventional data such as resident perceptions, and provided forums for productive public interactions and decisionmaking. Early successes, such as the approval of a zoning overlay district to permit housing in the city's historic mills, raised expectations among residents and civic leaders and gave all of us the confidence to do more.

The external validation of my work by way of the Lynton Award also strengthened my case for promotion. A tenured colleague informed me (off the record) that the award strengthened my dossier and contributed substantially to my promotion from assistant professor to associate professor without tenure. The award and the reframing of my narrative statement apparently assured some colleagues that the campus-city engagement, though taking place in the "swampy lowlands" where "problems are messy and incapable of technical solution," was indeed a rigorous a way of knowing "embedded in competent practice" (Schön, 1995, p. 28). The tenured faculty in my department voted unanimously to promote me from assistant professor to associate professor without tenure.

The Lynton Award also emboldened me to broaden my understanding of what constitutes scholarship. In the years that followed my promotion to associate professor without tenure, we 
continued to grow the partnership with the City of Lawrence. Our scholarly engagement tested and refined the theory and practice of "reciprocal knowledge" by way of collaborations among a variety of M.I.T. faculty, staff, students as well as civic leaders and residents. In addition to such scholarly artifacts as peer-reviewed journal articles and book chapters, we co-generated policy reports, special grants to fund development projects, 'how-to' guides, blog posts, webinars, and short films.

Our sustained engagement strengthened my research and teaching, while contributing to student learning and community development practice in Lawrence. Successive waves of students wrote theses that informed the development of Union Crossing, a LEED Platinum certified mill redevelopment project in downtown Lawrence. Middle school students from Lawrence came to M.I.T. every month to participate in chemistry, physics, biology, and civil engineering experiments. Faculty incorporated resident testimonies into their research on predatory lending and housing foreclosures. By way of our partnership, we created "a special climate in which the academic and civic cultures communicate more continuously and more creatively with one another" (Boyer, 1996, p. 251). Reciprocal knowledge, as we defined it, emerges as people learn the norms and advance the values of democracy by replacing longstanding habits of distrust with new institutional relationships; it is characterized by real learning on both sides, achieved through a diverse, dynamic, and complex network of human relationships (Hoyt, 2010).

The Lynton Award gave me the courage to experiment with the ways in which knowledge is generated and applied, and to overcome, rather than reinforce, the false dichotomy between practice and knowledge in the academy. It encouraged me to expand my relationships with people outside the walls of the university. In doing so, it transformed my experience of the university; the university became a place where I lived a fully conscious life, questioning and moving beyond that which appeared inescapable.

\section{The Practice of Freedom}

Education either functions as an instrument which is used to facilitate integration of the younger generation into the logic of the present system and bring about conformity or it becomes the practice of freedom, the means by which men and women deal critically and creatively with reality and discover how to participate in the transformation of their world.

\section{—Paulo Freire, Pedagogy of the Oppressed, 1968 (1996 Ed.)}

Before I received the Lynton Award, I felt isolated, afraid, and unable to free myself from the way I thought about scholarship and success in the academy. Though I was initially excited about joining M.I.T. after completing my doctoral degree, these feelings began to develop early in my tenure track journey. At my first faculty meeting, M.I.T.'s Provost presented findings from the newly published Reports of the Committees on the Status of Women Faculty. He explained to me and my colleagues that M.I.T. faculty women earned less than their male colleagues, were few in number (16\% of M.I.T. faculty were women), and reported feeling a lack of influence in important decision-making. The report noted that women faculty had won appointment to important committees; however, important departmental decisions take place outside of committee structures (M.I.T., 2002). The findings and the apparent lack of concern among the majority my colleagues were demoralizing and made an indelible impression. 
Due in large part to this stunning initiation to the academy, I became whole-heartedly committed to breaking the glass ceiling, so to speak. In my department, that would mean becoming the first female professor in its 75-year history to rise through the ranks from assistant professor to associate professor with tenure. Earning tenure became for me more than a personal achievement or pay increase; it was a matter of fighting for gender equality. I was also determined at the time to achieve tenure at M.I.T. in order to provide the full tuition remission benefit to my children. Though they were young at the time, the prospect of earning tenure at M.I.T. became a goal for our family; it symbolized the opportunity for the next generation to expand their knowledge and networks with minimal concern about the associated financial burdens. These two forcesfighting for all women and fighting for my family - drove me to work very long days, through weekends and holidays. I became increasingly fixated on tenure and the victory it might represent. For me, tenure became synonymous with success. Accordingly, I adopted the "publish or perish" mindset, compromising my health and my personal relationships. My research and writing aimed to impress senior faculty in my department and external reviewers. I aimed to achieve tenure at M.I.T. at any cost.

The Lynton Award set me free, and, in a way, saved my life. The opportunity to rub elbows with other engaged scholars prompted me to challenge my deep-seated beliefs about my role as a woman seeking tenure, my obligations as a parent, and my vision of what constitutes a successful career in the academy. The award ended my isolation at M.I.T. by connecting me with a cadre of engaged scholars throughout the Boston region and beyond. I discovered there were revolutionaries in academia. There were risk-takers and rebel rousers pushing against the traditional boundaries of the ivory tower, aligning their personal and professional values, and working with communities to generate new and relevant knowledge for purposeful action and societal betterment. Leading by example, they helped me to break free of the way I had been socialized as a doctoral student and later as a tenure-track faculty member. As these personal relationships and exchanges with engaged scholars in multiple disciplines grew, I recalibrated my approach to learning, doing, and knowing with the people of Lawrence. In time, I began to see myself as an activist scholar, committed to social impact and institutional change. My interest in reforming institutions of higher education emerged as my larger cause and calling, casting a shadow on and diminishing the importance of tenure.

As my promotion to tenure approached, I prepared my dossier of engaged scholarship. This dossier, I decided, would serve the greater cause by giving my tenured colleagues an opportunity "to incrementally enlarge the customary paradigm of knowledge generation in higher education by using reward systems such as tenure to assign value to new forms of scholarship" (Hoyt, 2010). The dossier included bold experiments such as The Collaborative Thesis Project. I coorganized this project with a group of six graduate students who shared my interest in modernizing the well-established thesis requirement. We decided together that each student member of the group would investigate the use or potential use of funds from the American Recovery and Reinvestment Act with community partners in cities across the United States. We met weekly to share discoveries, learn across cases, and troubleshoot research-related problems. In spring 2010, we disseminated ideas that cities could act on in the form of public presentations (in cities, on campus, and through webinars), short films, peer-to-peer blogs, and 'how-to' guides. Our collaboration also resulted in book entitled Transforming Cities and Minds through 
the Scholarship of Engagement: Economy, Equity and Environment (Hoyt, 2013). By discovering new modes of co-inquiry, co-learning, and co-production, we pushed the traditional boundaries of research and mentorship.

The success of this project gained public recognition when I received the M.I.T. Excellence in Advising Award. Also, my engaged scholarship and its impact on the field of urban planning and in the City of Lawrence was recognized when the President's Council on Service and Civic Participation named M.I.T. to the President's Higher Education Community Service Honor Roll. MIT@Lawrence won the Presidents' Community Partnership Award from Massachusetts Campus Compact, and I received the M.I.T. Martin Luther King Jr. Leadership Award.

My scholarship was integrated and prolific. I developed theories from practice, publishing accessible essays in high-ranking, peer-reviewed journals. My teaching evaluations were consistently among the very highest in a large department with dozens of course offerings. I served as the first faculty advisor to the M.I.T. student group Queers in the Built Environment (in 2009), which received M.I.T.'s John S. W. Kellet 47 Award, as well as the award for Contribution to Intellectual Life of the Department.

To my surprise, my department did not award me tenure at M.I.T. In fall 2010, the tenured faculty in my department, several of whom had assisted me with compiling a dossier of my engaged scholarship for promotion to tenure, met to discuss my promotion case. They decided by majority vote not to solicit external review letters. A tenured colleague who participated in the meeting later shared some insights with me: "We took a vote. Some thought your case should go out for review, and others did not. Turnout was low and people who did not attend did not get to vote. The decision was made forty-eight hours before the meeting." The news of their decision felt cruel and unfair to me at the time. Why would the colleagues with whom I had worked for several years (20022010) decide to deny me the opportunity to send my dossier to external reviewers? Why would they deny themselves the opportunity to hear what others had to say about my achievements, and the opportunity (Lynton, 1996, p. 2) to deliberate the definition of scholarship?

\section{A Revolution in Concepts}

The first level of the revolution is not a revolution in technology, machinery, techniques, software, or speed, but a revolution in concepts, and thus the way we think about issues. (Odora Hoppers, 2017, p. 2)

The Lynton Award led me to the ideas and people who have helped me to know who I am. The experience of being a Lynton Award winner has instilled in me a clarity of purpose and conviction that propels me forward during periods in my career when my confidence is low.

In 2011, I left M.I.T. and accepted a staff position as Director of Programs and Research for the Talloires Network, a sponsored program in the Tisch College of Civic Life at Tufts University. The Talloires Network is a global association of 388 engaged universities in 77 countries around the world. It was established in 2005 when then Tufts University President Lawrence S. Bacow convened a group of 29 university presidents, vice-chancellors and rectors from 23 countries at the Tufts European Center in Talloires, France. Together, this small group of university leaders made a public commitment to building a global network of engaged universities by producing 
and signing the Talloires Declaration on the Civic Roles and Social Responsibilities of Higher Education.

In my new position, I began managing all core programs and activities of the Network, and overall administration of its secretariat. Though it was humbling and disorienting to forego my faculty role, I was energized by the prospect of collaborating with and providing support to engaged scholars around the world. With network members and partners, I embedded several research questions in the Network's programmatic activities: How and why is university civic engagement developing and expanding internationally? What strategies hold particular promise for strengthening university civic engagement? What are the trends and driving factors in university civic engagement? What impact does university civic engagement have on the development of student capabilities? Motivated by curiosity to learn about other universitycommunity partnerships and liberated from the pressures of moving through the faculty ranks, I set out to rebuild my academic career at Tufts University.

The Network provided enormous inspiration. Early on, I discovered a program called Amplifying Community Voices (hereafter Voices). Created in 2006 at the University of Venda, a small public institution in South Africa, Voices engages people in collective deliberation and decisionmaking. Discussions include university faculty and students as well as youth, women, and the elderly in rural communities. Students from a variety of disciplines organize and lead "reflection circles" in dozens of villages in the Vhembe District near the university. Students learn how to ensure that all voices may speak, and no single voice dominates. By doing so, they learn about conflict, group dynamics, and how to recognize and handle power imbalances. Voices captures and contributes local knowledge to inform public development projects. Voices reinforces multidirectional flows of knowledge as municipal officials and university students and staff use the development plans to address such issues as water and sanitation, education, health, housing and transportation (Francis \& Kabiti, 2014). In this way, knowledge is "is everywhere fed back, constantly enhanced" (Lynton, 1994).

In 2013, I prepared a dossier for promotion and returned to a faculty role as an associate research professor (a multiple-year full-time appointment based on external funding; it is not a tenuretrack position) at Tufts University. I presented my action research on the history and development of national, regional and global networks for university civic engagement, their activities and strategies, and their aspirations for the future. The research demonstrated why such networks are positioned to address specific needs and issues of their social, cultural and geopolitical contexts, and how they function as intermediaries and build strong ties with their institutions. My findings suggested that networks for university civic engagement continue to grow in number, size of membership, and capability; they are influential vehicles for exchange of experience, professional training, and policy reform through collective voice and action. My research identified the factors driving the international university civic engagement movement: national governmental policies, institutional incentives and rewards, the changing expectations of external constituencies, and the visions and strategies of the latest generation of university heads.

I discovered that while there is significant variation with respect to goals, outcomes and nomenclatures across and within regions of the world, university civic engagement leaders share common vision and strategy. These leaders build their character and quality on the influence of 
regional values such as good citizenship, social responsibility, and social solidarity. They aim to address pervasive challenges to civic life, such as poverty, illiteracy, and disease using an array of approaches including service learning, volunteerism, extension, participatory action research and applied research. Service-learning is the most common pedagogical approach and it is practiced in all regions and many countries of the world, in all fields of study and in public and private universities, large and small.

My promotion dossier included a comparative research study of exemplary university engagement programs in different institutional and geopolitical settings (Australia, Egypt, Malaysia, Mexico, Scotland, South Africa, and United States). In this project, seven pairs of authors, each consisting of an academic and either a community practitioner or a student, produced case studies to answer the questions: What capacities do students need in order to participate effectively in their societies as active and responsible citizens? What practices are universities around the world using to engage students in communities more effectively? What difference have these practices made in the civic capacities of students? These exemplary engagement programs reach beyond traditional community service learning approaches. They are producing greater student skills in managing conflict and bridging cultural divisions, building community assets, and addressing fundamental political challenges to build inclusive systems of power. Michigan State University Press published this project and made it part of its Scholarship of Engagement Series.

Later, I updated my dossier for external review by leaders in the field. Due in large part to administrative ambiguities, personnel changes, and other challenges, the internal process was replete with twists, turns, and lengthy pit stops. However, I benefited from the strong and consistent support of many colleagues who understood the merits of engaged scholarship, valued my contributions, and knew how to navigate the institution. By the end of 2017, I was promoted to Research Professor in the Department of Urban and Environmental Policy and Planning at Tufts University (Research Professors enjoy the same rights and responsibilities as tenured full professors at Tufts University; it is a multiple-year full-time appointment based on external funding).

The old wounds have healed, I am living my dream, and the cause is more urgent and consequential than tenure. As professor and executive director of the Talloires Network, I envision the greater cause as a project in strengthening the global university civic engagement movement. In practical terms, this means realizing the special obligation of universities as civic institutions to enhance human dignity and well-being and improve social harmony and stability. A few examples among our members include: clinics for dental care that reduces oral health inequality in England; a project to rebuild a school that was destroyed by a flood in Pakistan; an initiative to provide women with seed capital to start a business in Mexico; and a refugee support program in Australia that prepares future teachers while assisting young, unaccompanied minors from Iraq, Sudan, Afghanistan, and Sierra Leone.

\section{Call to Action}

This [modern] university is a network or web of many nodes, each closely connected to all the others, and it engages in continuous two-way interaction with its environment. It is an institution that still has a clear identity as a whole but is less defined and less 
compartmentalized than the traditional university. (Lynton \& Elman, 1987, p. 161)

As governments around the world move higher education from the margins to the forefront of their agendas, and higher education participation rates continue to rise around the world, the debate about the role of the university is no longer a theoretical exercise. It a pressing question demanding thoughtful action. What do you believe the societal role of the university to be? Is it an engine for technological advances and economic growth for the public good? Is a site of critical inquiry and engaged citizenship? Is it a market-driven provider of skills for the purpose of individual economic security?

Universities are rooted and durable community institutions (Harkavay, 2011). In this way, they are perfectly positioned to respond to the pressing challenges of our time. Like many human institutions, they exhibit inertia and are slow to change. Can we afford to watch from the sidelines, as rising authoritarianism and the disintegration of democracy around the world redefine the popular perception of higher education? It is already reducing universities to brands, degrees to commodities, and students to customers. Might we articulate and proactively advance a broader social understanding of the university?

What forces will drive and shape the role of the university in the $21^{\text {st }}$ century? Shall they be the demands of $21^{\text {st }}$ century students who expect to customize their learning to fit their distinctive needs? Will there be decreasing public support for universities? Will multiple factors bring mounting global competition among universities? To say nothing of pressing societal issues, including population growth, rising levels of inequality, human conflict and migration, and food and water insecurity. Powerful technological advancements including artificial intelligence and its impact on the nature of work and the realities of human consciousness.

Three decades ago, Lynton and Elman (1987) suggested that the university in the $21^{\text {st }}$ century would be a "web of many nodes" engaging "in continuous two-way interaction" with communities. In many ways, their vision is unfolding. I believe that the university as we know it will necessarily evolve into a nimble and responsive network of engaging spaces, physical and virtual, synchronous and asynchronous. Popular contemporary characteristics such as sage on the stage, standardized testing, disciplinary research, semesters, and specialized degrees will fade away. New ideas including reciprocal knowledge, impact-based assessments, transdisciplinary action research, continuous and on-demand learning, and collaborative problem-solving credentials and micro-degrees will emerge and take hold.

I invite you to ask yourself, where do I stand? In the end, what difference will my scholarship make in the world? In what ways does my research, teaching, and administrative leadership within higher education contribute to human dignity and wellbeing? If you are working in a geopolitical location where you may speak freely, and take a stand for justice without facing the risk of unlawful imprisonment, I ask you to exercise your power. Now is the time for bold action. By taking action, you will contribute to the growing global university civic engagement movement.

A case in point is the newly-elected Vice-Chair of the Talloires Network Steering Committee, Dr. Sara Ladrón de Guevara. Ladrón became Rector of Universidad Veracruzana in 2013 and was re-elected for a second four-year term in 2017. She is the first woman to hold this prestigious position in the 75-year history of the university. Her leadership as Rector has 
proceeded from a profound commitment to social justice and activism for speaking out against corruption. In 2016, she organized and led a 60,000-person statewide protest to demand the university's public funds from the state government. This protest has come to symbolize the defense of the right to higher education (Ladrón \& Monaco, 2017).

\section{Conclusion}

In closing, I urge you to join the movement, as we take larger and more rapid strides toward "the new scholarship" (Schön, 1995, p. 32). It is time to evolve beyond the "battle of snails." The generative utility and relative permanence of higher education institutions suggests they may have a vital role in contributing to our collective survival, if they are able to evolve quickly and purposefully. Incremental adaptation, resistance to or denial of the changing global order are no longer viable options for institutions, especially universities. Let us continue to move forward, and with a heightened sense of urgency, creativity, and fearlessness.

\section{Engaging Spaces}

We have created violent places for suffering, where many voices are excluded; practicing conformity of thought...conformity of deed.

Places that polarize and divide us, where we doubt each other's motives and ways, accepting false boundaries and limitations.

Places that generate waves of unrest, where we lose our footing and faith;

Retreating from ideals of agency and cooperation.

Places that diminish our imaginations, where we abuse power and destroy hope, seeking dominance over the other.

We need engaging spaces to move through, where all are welcome; practicing freedom of thought... freedom of deed.

Spaces that respond to our ever-changing needs, where we grow, endure, and thrive; imagining and achieving limitless possibilities,

Spaces to struggle and learn together, where we explore and discover beauty; inventing new opportunities for prosperity.

Spaces that nourish our aspirations, where we recreate systems of power; seeking dignity and wellbeing for humanity

... again and again. 


\section{References}

Bacow, L. S. (2011). Foreword. In D. Watson, R.M. Hollister, S.E. Stroud \& E. Babcock, The engaged university: International perspectives on civic engagement. Routledge, New York \& London.

Boyer. E. L. (1996). The scholarship of engagement. Journal of Public Service and Outreach 1 (1), 11-20. https://doi.org/10.2307/3824459

Francis, J. \& Kabiti, H. (2014). Amplifying community voices for people-centered development in South Africa. Unpublished paper, Venda, South Africa.

Freire, P. (1996). Pedagogy of the oppressed. Trans. M. B. Ramos. Rev. ed. London: Penguin.

Harkavay, I. (2011). Forward. In LeDoux, M.W., S.C. Wilwhite, \& P. Silver, Civic Engagement and Service Learning in a Metropolitan University: Multiple Approaches and Perspectives (pp. xiii-xv). Philadelphia, PA: University of Pennsylvania Press.

Higgins, M.D. (2016 April 16). What is the role of the university in the digital age? University World News 409. Retrieved from http://www.universityworldnews.com/article.php?story=20160412194215660

Odora Hoppers, C. (2017). Transformation and Change in Knowledge Generation Paradigms in the African and Global Contexts: Implications for Education Research in the 21 st Century. Educational Research for Social Change 6 (1), 1-11. https://doi.org/10.17159/2221$\underline{4070 / 2017 / v 6 i 1 a 1}$

Hoyt, L. (2010). A City-Campus Engagement Theory From, and For, Practice. Michigan Journal of Community Service Learning 17 (1), 75-88.

Hoyt, L. (2014). University Civic Engagement: A Global Perspective. Higher Education Exchange. Dayton: Kettering Foundation. Retrieved from https://eric.ed.gov/?id=ED560889

Hoyt, L. et al. (2017). University Entrepreneurship Education for Individual and Community Transformation. Toronto, Canada: Mastercard Foundation. Retrieved from https://talloiresnetwork.tufts.edu/wp-content/uploads/YEPI-Report-1.pdf

Ladrón, S. \& Monaco, A.P. (2017 June 18). Community spirit: Universities redefining how students learn. Times Higher Education. Retrieved from https://talloiresnetwork.tufts.edu/wpcontent/uploads/Community-spirit-Ladron-de-Guevara-and-Monaco-.pdf

Lynton, E. A. \& Elman, S. E. (1987). New Priorities for the University: Meeting Society's Needs for Applied Knowledge and Competent Individuals. Jossey-Bass Publishers. San Francisco.

Lynton, E. A. (1994). Knowledge and Scholarship. Metropolitan Universities: An International Forum, 5 (1), 9-17. Retrieved from https://journals.iupui.edu/index.php/muj/article/download/19385/19144 
Lynton, E. A. (1996). Rethinking the nature of scholarship. International Higher Education 6, $2-$ 3. https://doi.org/10.6017/ihe.1996.6.6217

MIT Faculty Governance. (2002 March). Reports of the Committees on the Status of Women Faculty. Retrieved from https://facultygovernance.mit.edu/sites/default/files/reports/200203_Status_of_Women_Faculty-All_Reports.pdf

Saltmarsh, J. (2016). Ernest Lynton and the tyranny of research. Journal of Higher Education Outreach and Engagement 20 (1), 45-51. Retrieved from

http://openjournals.libs.uga.edu/index.php/jheoe/article/download/1592/911

Schön, D. A. (1995). Knowing-in-action: The new scholarship requires a new epistemology.

Change 27 (6), 26-34. https://doi.org/10.1080/00091383.1995.10544673

Talloires Network. (2017 June 23). Veracruz Declaration on Social Responsibility and Human Dignity in Higher Education Engagement. Retrieved from https://talloiresnetwork.tufts.edu/wpcontent/uploads/VeracruzDeclaration_English_with-signatures.pdf 


\section{Author Information}

Pr. Lorlene M. Hoyt

Executive Director of the Talloires Network

Dearborn House

Tufts University

72 Professors' Row, Rm. 108

Medford, MA 02155

Telephone: (617)-627-6056

Email: lorlene.hoyt@tufts.edu

Dr. Lorlene Hoyt is a Research Professor in the Department of Urban and Environmental Policy and Planning, a faculty member of the Tisch College of Civic Life at Tufts University, and the Executive Director of the Talloires Network, a global network of 388 engaged universities in 77 countries. She has published in numerous academic journals, and she is the author of Transforming Cities and Minds through the Scholarship of Engagement, a book she wrote with a group of six M.I.T. students. More recently, she coordinated a research and writing collaboration with engaged scholars who are leading exemplary university civic engagement programs in seven countries on six continents. Their collective work entitled Regional Perspectives on Learning-by-Doing: Stories from Engaged Universities around the World was published by Michigan State University Press. 